\title{
Pengembangan Model Sistem Pendukung Keputusan Dengan Kombinasi Metode Fuzzy Tahani Dan Topsis Dalam Penilaian Kinerja Instruktur
}

\author{
Safrizal $^{1}$, Susianto ${ }^{2}$ \\ Program Studi Manajemen Informatika, Fakultas Teknik dan Ilmu Komputer, Universitas \\ Potensi Utama \\ Universitas Potensi Utama; Jl. KL. Yos Sudarso Km. 6,5 No. 3-A Tanjung Mulia, \\ Telp. (061) 6640525/fax : (061) 6636830 \\ Rizalsyl75@yahoo.co.id
}

\begin{abstract}
The instructor is the main academic implementer in the Institute for Aviation Education and Training (LPP). One of the factors that influence the success of LPP Aviation in improving student quality is the commitment and performance of instructors. One method used is to conduct an instructor performance appraisal process. The large number of Instructors in LPP Aviation is a separate issue in the assessment process, considering the process is based on subjectivity and has a great chance of making mistakes in the decision making, namely the selection of instructors who do not meet the desired standards and are not in accordance with the determination of instructor performance evaluation priorities. For this reason, a decision support system is needed in conducting the instructor's performance appraisal process. The Multi Attribute Decision Making (MADM) model has been widely used by decision makers to solve decision making problems with a variety of methods that can be used to find the best solution, but from these methods can still be developed with the aim of providing maximum decision results. In this research a decision support system model will be built with a combination of two methods, namely the Fuzzy Resistant method and TOPSIS which aims to manipulate the success data of instructors who are ambiguous by conducting a search for appropriate and accurate data for the criteria used in the assessment process LPP Aviation instructor performance by using Fuzzy-Resistant to get priority criteria in the form of rules, then ranking will be done by using TOPSIS in getting the quality of teaching conducted by LPP Aviation Instructors as the best instructor selection. The results of the flight instructor's performance evaluation with a combination of the Fuzzy Resistant method and TOPSIS, are based on 250 data tested samples, therefore, the accuracy value is $93 \%$.
\end{abstract}

Keywords: Decision Support System, Instructor Performance Assessment, Fuzzy Resistant, TOPSIS

\begin{abstract}
Abstrak
Instruktur merupakan pelaksana akademik utama didalam Lembaga Pendidikan dan Pelatihan (LPP) Penerbangan. Salah satu faktor yang mempengaruhi keberhasilan LPP Penerbangan dalam meningkatkan kualitas siswa adalah komitmen dan kinerja para instruktur. Salah satu cara yang digunakan adalah dengan melakukan proses penilaian kinerja instruktur. Banyaknya jumlah Instruktur di LPP Penerbangan menjadi masalah tersendiri dalam proses penilaian, mengingat prosesnya berdasarkan subjektivitas dan berpeluang besar terjadinya kesalahan dalam menghasilkan keputusan yaitu terpilihnya instruktur yang tidak memenuhi standar yang diinginkan dan tidak sesuai dengan penentuan prioritas penilaian kinerja instruktur. Untuk itu diperlukan sebuah sistem pendukung keputusan dalam melakukan proses penilaian kinerja instruktur. Model Multi Attribute Decision Making (MADM) sudah banyak digunakan oleh pengambil keputusan untuk menyelesaikan permasalahan pengambilan keputusan dengan berbagai macam metode yang dapat digunakan untuk mencari solusi terbaik, namun dari metode-metode tersebut masih dapat dikembangkan
\end{abstract}


dengan tujuan agar memberikan hasil keputusan yang maksimal. Dalam penelitian ini akan dibangun sebuah pemodelan sistem pendukung keputusan dengan kombinasi dua metode yaitu metode Fuzzy Tahani dan TOPSIS yang bertujuan untuk melakukan manipulasi data-data keberhasilan Instruktur mengajar yang bersifat ambigu dengan cara melakukan pencarian data yang tepat dan akurat untuk kriteria yang dipakai dalam proses penilaian kinerja instruktur LPP Penerbangan dengan menggunakan Fuzzy-Tahani untuk mendapatkan perioritas kriteria dalam bentuk rule, kemudian akan dilakukan perangkingan dengan menggunakan TOPSIS dalam mendapatkan kualitas pengajaran yang dilakukan oleh Instruktur LPP Penerbangan sebagai pemilihan intruktur terbaik. Hasil penilaian kinerja instruktur penerbangan dengan kombinasi metode Fuzzy Tahani dan TOPSIS, berdasarkan pada 250 data yang diuji sampel, oleh karena itu, nilai akurasi adalah sebanyak $93 \%$.

Kata kunci : Sistem Pendukung Keputusan, Penilaian Kinerja Instruktur, Fuzzy Tahani, TOPSIS

\section{PENDAHULUAN}

Instruktur merupakan pelaksana akademik utama didalam lembaga pendidikan dan pelatihan penerbangan. Salah satu faktor yang mempengaruhi keberhasilan LPP Penerbangan dalam meningkatkan kualitas siswa adalah komitmen dan kinerja para instruktur. Salah satu cara yang digunakan untuk meningkatkan kualitas siswa dan keberhasilan Lembaga Pendidikan dan Pelatihan (LPP) Penerbangan adalah dengan melakukan proses penilaian kinerja instruktur. Banyaknya jumlah Instruktur di LPP Penerbangan menjadi masalah tersendiri dalam proses penilaian, mengingat prosesnya berdasarkan subjektivitas dan berpeluang besar terjadinya kesalahan dalam menghasilkan sebuah keputusan yaitu terpilihnya instruktur yang tidak memenuhi standar yang diinginkan dan tidak sesuai dengan penentuan prioritas penilaian kinerja instruktur. Untuk itu diperlukan sebuah pemodelan sistem pendukung keputusan dalam melakukan proses penilaian kinerja instruktur. Pemodelan dari sebuah pengambilan keputusan digunakan untuk mengatasi permasalahan yang sering terjadi untuk membantu dalam pengambilan sebuah keputusan yang tepat sehingga dapat mencari solusi yang terbaik [1][19]. Model MADM sudah banyak digunakan oleh pengambil keputusan untuk menyelesaikan permasalahan pengambilan keputusan dengan berbagai macam metode yang dapat digunakan untuk mencari solusi terbaik[1], diantaranya seleksi karyawan untuk kualifikasi pekerjaan yang terbaik dengan menggunakan fuzzy TOPSIS[2], penilaian kinerja Kepala Sekolah dengan menggunakan metode TOPSIS[3], metode AHP dan TOPSIS dalam pemilihan guru berprestasi[4], rekam jejak dosen sebagai model pengambilan keputusan dalam pemilihan dosen berprestasi dengan penerapan metode AHP[5], multi-criteria decision making dalam penentuan jurusan siswa pada lembaga pendidikan dan pelatihan (LPP) penerbangan[6], evaluasi kinerja instruktur untuk meningkatkan profesionalisme pada lembaga pendidikan dan pelatihan penerbangan dengan metode AHP[7], monitoring dan evaluasi kinerja instruktur 
penerbangan dengan metode PROMETHEE[8]. Namun dari metode-metode tersebut masih dapat dikembangkan dengan tujuan agar memberikan hasil keputusan yang maksimal dikarenakan dari beberapa metode MCDM memiliki kelemahan yaitu belum adanya penentuan bobot prioritas yang menjadi prioritas hitungan terhadap kriteria guna untuk meningkatkan validitas nilai bobot perhitungan kriteria. Maka dengan alasan ini, metode ini dapat di kombinasikan adalah dengan metode Fuzzy Tahani agar menghasilkan output atau keputusan yang lebih maksimal. Dalam penelitian ini akan dibangun sebuah pemodelan sistem pendukung keputusan dengan kombinasi dua metode yaitu metode Fuzzy Tahani dan TOPSIS yang bertujuan untuk melakukan manipulasi data-data keberhasilan Instruktur mengajar yang bersifat ambigu dengan cara melakukan pencarian data yang tepat dan akurat untuk kriteria yang dipakai dalam proses penilaian kinerja instruktur LPP Penerbangan dengan menggunakan Fuzzy-Tahani untuk mendapatkan perioritas kriteria dalam bentuk rule, kemudian akan dilakukan perangkingan dengan menggunakan TOPSIS dalam mendapatkan kualitas pengajaran yang dilakukan oleh Instruktur LPP Penerbangan sebagai pemilihan intruktur terbaik dan tingkat keberhasilan instruktur yang dapat meningkatkan kualitas proses belajar mengajar sehingga mampu meningkatkan nilai akademik siswa.

\section{Metodologi Penelitian}

Metode penelitian merupakan tahapan yang akan dilakukan untuk mempermudah dalam melakukan penelitian. Metode penelitian yang digunakan pada analisis pengembangan model sistem pendukung keputusan dengan kombinasi metode Fuzzy Tahani dan TOPSIS dalam penilaian kinerja instruktur adalah sebagaimana digambarkan pada gambar 1.

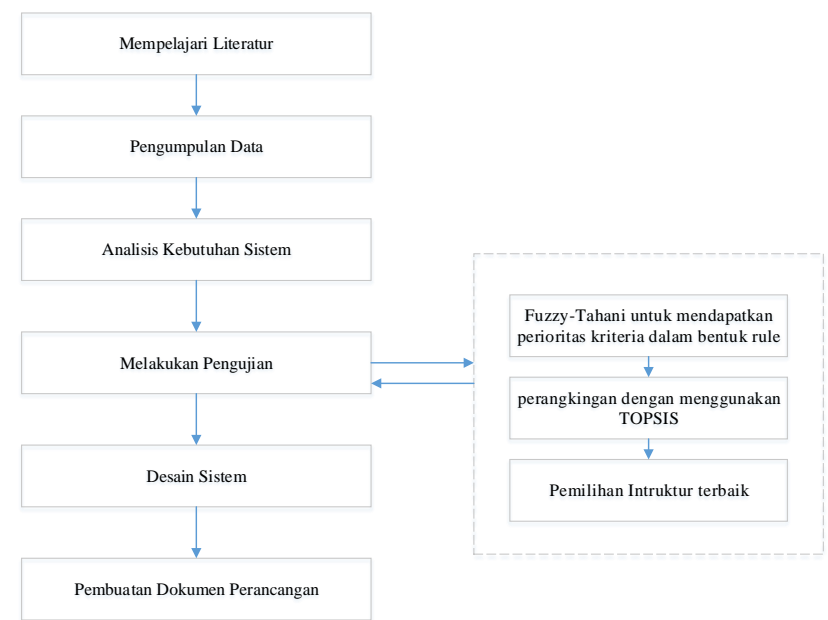

Gambar 1. Metode Penelitian Pengembangan Model Sistem Pendukung Keputusan dengan kombinasi metode Fuzzy Tahani dan TOPSIS dalam penilaian kinerja instruktur 
Metode penelitian yang digambarkan pada gambar 1, menjelaskan mengenai tahap-tahap penelitian dalam pengembangan Model Sistem Pendukung Keputusan dengan kombinasi metode Fuzzy Tahani dan TOPSIS dalam penilaian kinerja instruktur yaitu meliputi tahap pertama mempelajari literature, dimana pada tahap ini bertujuan untuk memperdalam dan memahami mengenai teori maupun metode yang akan digunakan dalam memecahkan permasalahan yang ada. Studi literature dilakukan dengan mencari literatur yang dipelajari pada tahap ini adalah mengenai metode fuzzy tahani dan metode TOPSIS dan proses penilaian kinerja instruktur pada Lembaga Pendidikan dan Pelatihan (LPP) Penerbangan. Tahap kedua yaitu pengumpulan data, dimana pada tahap ini ditentukan data yang akan digunakan pada penelitian. Proses menentukan data penelitian ini akan sangat berguna pada saat pengumpulan data. Pada tahap inilah ditentukan data apa saja yang akan dibutuhkan dalam mencari data tentang penentuan penilaian kinerja instruktur dengan cara melakukan Observasi, Survei dan Analisis data. Tahap ketiga adalah analisis kebutuhan system, dimana tahap ini data yang telah dikumpulkan akan dianalisis, untuk mendata kebutuhan apa saja yang dibutuhkan pada penelitian ini, baik secara fisik maupun sistem. Tahap keempat yaitu melakukan pengujian, dimana tahap ini bertujuan untuk melakukan proses pengolahan data dari hasil data yang didapat dari tahap pengumpulan data yang didapat dari pihak Lembaga Pendidikan dan Pelatihan (LPP) Penerbangan dimana hal tersebut dilakukan untuk mencari hubungan antara setiap variabel/kriteria yang mendukung dalam penilaian kinerja instruktur dengan melakukan kombinasi pengujian menggunakan metode fuzzy tahini dan TOPSIS. Dimana data tersebut tersebut diolah dengan menggunakan metode fuzzy tahani untuk mendapatkan perioritas kriteria dalam bentuk rule, kemudian akan dilakukan perangkingan dengan menggunakan TOPSIS dalam mendapatkan kualitas pengajaran yang dilakukan oleh Instruktur LPP Penerbangan sebagai pemilihan intruktur terbaik dan tingkat keberhasilan instruktur yang dapat meningkatkan kualitas proses belajar mengajar sehingga mampu meningkatkan nilai akademik siswa. Tahap kelima yaitu melakukan desain system dengan UML. UML digunakan untuk menggambarkan alur logika program, lengkap dengan class-class yang akan digunakan dalam alur tersebut, sifat-sifat class-nya, perubahan objek-nya, serta metode yang dapat digunakan [9]. Terdapat beberapa diagram untuk penggambaran UML, diantaranya; usecase diagram, class diagram, sequence diagram, activity diagram. Tahap terakhir yaitu pembuatan dokumen perancangan, Ini adalah tahapan terakhir dari sebuah perancangan sistem. Pada tahap ini, dilakukan penggabungan hasil pekerjaan sebelumnya agar menjadi sebuah dokumen yang lengkap serta mudah dipahami oleh pihak-pihak yang akan melanjutkan proses rekayasa perangkat lunak ini. 


\section{HASIL DAN PEMBAHASAN}

\subsection{Deskripsi Masalah}

Instruktur merupakan pelaksana akademik utama didalam lembaga pendidikan dan pelatihan penerbangan. Salah satu faktor yang mempengaruhi keberhasilan LPP Penerbangan dalam meningkatkan kualitas siswa adalah komitmen dan kinerja para instruktur. Salah satu cara yang digunakan untuk meningkatkan kualitas siswa dan keberhasilan Lembaga Pendidikan dan Pelatihan (LPP) Penerbangan adalah dengan melakukan proses penilaian kinerja instruktur. Banyaknya jumlah Instruktur di LPP Penerbangan menjadi masalah tersendiri dalam proses penilaian, mengingat prosesnya berdasarkan subjektivitas dan berpeluang besar terjadinya kesalahan dalam menghasilkan sebuah keputusan yaitu terpilihnya instruktur yang tidak memenuhi standar yang diinginkan dan tidak sesuai dengan penentuan prioritas penilaian kinerja instruktur.

\subsection{Analisis Kebutuhan Data}

Data yang dibutuhkan untuk pembuatan sistem ini adalah sebagai berikut:

a. Data Intruktur

Yaitu data instruktur yang dipilih sebagai sampel yang digunakan peneliti dalam melakukan proses penilaian kinerja instruktur dalam menentukan instruktur yang terbaik. Adapun sampel yang digunakan sebanyak 20 (dua puluh) intruktur.

\section{b. Data Nilai Variabel}

Data nilai variabel didapatkan dari hasil wawancara dengan pihak Lembaga Pendidikan dan Pelatihan (LPP) Penerbangan (tabel 1). Dari hasil wawancara di lapangan tersebut, maka didapatkan beberapa variable yang menjadi tolak ukur prioritas suatu Keputusan penilaian kinerja instruktur pada LPP Penerbangan. Variabel terbagi menjadi 5 himpunan Fuzzy yaitu: Tidak Baik, Kurang Baik, Cukup, Baik dan Sangat Baik. Himpunan tidak baik dan sangat baik menggunakan pendekatan fungsi keanggotaan bahu, sedangkan himpunan kurang baik, cukup dan baik menggunakan pendekatan fungsi keanggotaan segitiga. Perhitungan nilai berdasarkan pada kuesioner yang di bagikan kepada 250 siswa LPP Penerbangan dimana Penilaian didapat dari jumlah responden yang memilih himpunan berdasarkan kriteria. Total responden adalah jumlah siswa yang memberi penilaian terhadap kinerja instruktur. Bobot nilai tidak baik adalah 1 , kurang baik adalah 2 , cukup adalah 3 , baik adalah 4 dan sangat baik adalah 5 . Scoring didapat dengan mengalikan penilaian dengan bobot nilai masing-masing himpunan. Total nilai adalah total scoring berdasarkan kriteria. Hasil penilaian didapat dari total nilai dibagi 5 dikali total responden kemudian dikalikan dengan 100. 
Jurnal Sains Komputer \& Informatika (J-SAKTI)

Volume 3 Nomor 2 September 2019, pp. 227-242

ISSN:2548-9771/EISSN:2549-7200

http://tunasbangsa.ac.id/ejurnal/index.php/jsakti

Tabel 1. Variabel Penilaian Kinerja Instruktur

\begin{tabular}{|c|c|c|c|}
\hline Jenis & No & Kode & Variabel \\
\hline $\begin{array}{l}\text { Kualifikasi } \\
\text { Akademik }\end{array}$ & 1 & $\mathrm{C} 1$ & Jenjang Pendidikan \\
\hline \multirow{7}{*}{ Pedagodik } & 2 & $\mathrm{C} 2$ & Kesiapan memberikan materi dan/atau praktek/praktikum \\
\hline & 3 & $\mathrm{C} 3$ & Keteraturan dan ketertiban penyelenggaraan pelajaran \\
\hline & 4 & $\mathrm{C} 4$ & Kemampuan menghidupkan suasana kelas \\
\hline & 5 & $\mathrm{C} 5$ & $\begin{array}{l}\text { Kejelasan penyampaian materi dan jawaban terhadap pertanyaan } \\
\text { di kelas }\end{array}$ \\
\hline & 6 & C6 & Pemanfaatan media dan teknologi pembelajaran \\
\hline & 7 & C7 & Pemberian umpan balik terhadap tugas \\
\hline & 8 & $\mathrm{C} 8$ & Kesesuaian materi ujian dan/atau tugas dengan tujuan materi \\
\hline \multirow{5}{*}{ Profesional } & 9 & $\mathrm{C9}$ & Kemampuan menjelaskan pokok bahasan/topik secara tepat \\
\hline & 10 & C10 & Kemampuan memberi contoh relevan dari konsep yang diajarkan \\
\hline & 11 & $\mathrm{C} 11$ & $\begin{array}{l}\text { Kemampuan menjelaskan keterkaitan bidang/topik yang } \\
\text { diajarkan dengan bidang/topik lain }\end{array}$ \\
\hline & 12 & C12 & $\begin{array}{l}\text { Kemampuan menjelaskan keterkaitan bidang/topik yang } \\
\text { diajarkan dengan konteks kehidupan }\end{array}$ \\
\hline & 13 & C13 & Penguasaan akan isu-isu muktahir dalam bidang yang diajarkan \\
\hline \multirow{5}{*}{ Kepribadian } & 14 & C14 & Penguaan akan isu-isu muktahir ya \\
\hline & 15 & C15 & Kearifan dalam mengambil keputusan \\
\hline & 16 & C16 & Menjadi contoh dalam bersikap dan berperilaku \\
\hline & 17 & $\mathrm{C} 17$ & $\begin{array}{l}\text { Satunya kata dan tindakan, serta adil dalam memperlakukan } \\
\text { siswa }\end{array}$ \\
\hline & 18 & C18 & $\begin{array}{l}\text { Kemampuan mengendalikan diri dalam berbagai situasi dan } \\
\text { kondisi }\end{array}$ \\
\hline \multirow{5}{*}{ Sosial } & 19 & C19 & Kemampuan menyampaikan pendapat \\
\hline & 20 & $\mathrm{C} 20$ & Kemampuan menerima kritik, saran, dan pendapat orang lain \\
\hline & 21 & $\mathrm{C} 21$ & Mengenal dengan baik siswa yang mengikuti pelajaran \\
\hline & 22 & $\mathrm{C} 22$ & Mudah bergaul di kalangan sejawat, karyawan dan siswa \\
\hline & 23 & $\mathrm{C} 23$ & Toleransi terhadap keragaman siswa \\
\hline \multirow{5}{*}{$\begin{array}{l}\text { karya kreatif } \\
\text { atau inovatif }\end{array}$} & 24 & $\mathrm{C} 24$ & Pembaruan (inovasi) dalam pembelajaran atau bimbingan \\
\hline & 25 & $\mathrm{C} 25$ & Penemuan teknologi tepat guna dalam bidang pendidikan \\
\hline & 26 & $\mathrm{C} 26$ & Penulisan buku di bidang pendidikan \\
\hline & 27 & $\mathrm{C} 27$ & Penciptaan karya seni \\
\hline & 28 & $\mathrm{C} 28$ & Karya atau prestasi di bidang olahraga \\
\hline $\begin{array}{l}\text { Membimbing } \\
\text { Peserta } \\
\text { Didik }\end{array}$ & 29 & $\mathrm{C} 29$ & $\begin{array}{l}\text { Membimbing peserta didik hingga mencapai prestasi di bidang } \\
\text { intrakurikuler dan/atau ekstrakurikuler }\end{array}$ \\
\hline
\end{tabular}

\section{c. Data Penilaian Kinerja Instruktur}

Hasil dari perhitungan nilai berdasarkan pada kuesioner yang di bagikan kepada 250 siswa yang ditunjukkan pada tabel 2 (C1-C15) dan table 3 (C16-C29). 
Jurnal Sains Komputer \& Informatika (J-SAKTI)

Volume 3 Nomor 2 September 2019, pp. 227-242

ISSN:2548-9771/EISSN:2549-7200

http://tunasbangsa.ac.id/ejurnal/index.php/jsakti

Tabel 2. Data Hasil Penilaian Kinerja Instruktur berdasarkan Kuesioner (C1-

C15)

\begin{tabular}{|c|c|c|c|c|c|c|c|c|c|c|c|c|c|c|c|c|c|}
\hline \multirow{2}{*}{ no } & \multirow{2}{*}{$\begin{array}{c}\text { Nomor } \\
\text { Induk } \\
\text { Instruktur }\end{array}$} & \multirow{2}{*}{ Nama Instruktur } & \multicolumn{15}{|c|}{ Hasil Penilaian } \\
\hline & & & C1 & C2 & C3 & C4 & C5 & C6 & C7 & C8 & C9 & C10 & C11 & C12 & C13 & C14 & C15 \\
\hline 1 & IST-00001 & & 60 & 98,57 & 96,43 & 96,43 & 95,00 & 4,29 & 97,14 & 6,43 & 8,57 & 6,43 & 5,71 & 91,43 & 3,57 & 7,14 & 97,14 \\
\hline 2 & IST-0 & $\mathrm{ma}$ & 65 & 81,25 & 7,50 & 80,00 & 80,00 & 8,75 & 8,75 & 0,00 & 8,75 & 8,75 & 1,25 & 1,25 & 8,75 & 0,00 & 30,00 \\
\hline 3 & IST-00003 & 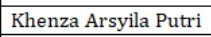 & 70 & 78,46 & 80,00 & 80,00 & 80,00 & 80,00 & 81,54 & 78,46 & 3,08 & 80,00 & 0,00 & 81,54 & 30,00 & 0,00 & 80,00 \\
\hline 4 & IST-00004 & Syafrizal & 80 & 73,33 & 70,00 & 70,00 & 73,33 & 83,33 & 56,67 & 80,00 & 3,33 & 73,33 & 3,33 & 66,67 & 76,67 & 33,33 & 76,67 \\
\hline 5 & IST-00005 & $\mathrm{Lu}$ & 80 & 64,00 & 63,88 & 60,60 & 61,80 & 64,00 & 65,65 & 64,00 & 7,67 & 64,00 & 0,00 & 66,50 & 00 & 00 & 68,80 \\
\hline 6 & $\begin{array}{l}\text { IST-00006 } \\
\end{array}$ & $M_{3}$ & 80 & 73,33 & 70,83 & 73,33 & 78,33 & 79,17 & 71,67 & 73,33 & 17 & 76,67 & 33 & 70,00 & 17 & 50 & \\
\hline 7 & IST-C & & 65 & & 80,00 & & 70,00 & & & & & & & & 00 & & \\
\hline 8 & IST-0 & & & & & & & & & & & & & & 71 & & \\
\hline 9 & IST-C & & 80 & & 9 & & 79,09 & & & & & & & & 09 & & \\
\hline 10 & IST- & & 7 & & & & & & & & & & & & 80 & & \\
\hline 11 & IST- & & 70 & & & & 91 & & 67 & & & & & & 33 & & \\
\hline 12 & IST & & 70 & 96,43 & 96,43 & 96,43 & 95,71 & 93,57 & 96,43 & & 7,14 & 95,71 & 43 & 95,00 & 97,14 & 43 & 95,71 \\
\hline 13 & IST & & 65 & 82,11 & 80,00 & 80,00 & 78,95 & 77,89 & 81,05 & & 16 & 82,11 & 00 & 74,74 & 81,05 & 11 & 81,05 \\
\hline 14 & IST-C & & 60 & 87,10 & 87,74 & 87,74 & 87,10 & 87,10 & 87,74 & & 7,10 & 87,10 & 7,74 & 87,74 & 9,03 & 74 & 87,74 \\
\hline 15 & IST-00015 & $\operatorname{Re}$ & 80 & 93,08 & 92,31 & 92,31 & 90,00 & 89,23 & 93,85 & 92,31 & 91,54 & 90,77 & 9,23 & 92,31 & 4,62 & 3,85 & 92,31 \\
\hline 16 & IST-00016 & Ozi syan & 70 & 75,00 & 75,00 & 75,00 & 70,00 & 70,00 & 70,00 & 75,00 & 75,00 & 75,00 & 5,00 & 75,00 & 5,00 & 0,00 & 70,00 \\
\hline 17 & \begin{tabular}{|l|} 
IST-00017 \\
\end{tabular} & Darwin & 65 & 71,11 & 71,11 & 66,67 & 72,22 & 68,89 & 68,89 & 68,89 & 68,89 & 67,78 & 8,89 & 68,89 & 57,78 & 8,89 & 68,89 \\
\hline 18 & IST-00018 & Gusdia & 60 & 70,43 & 72,17 & 73,91 & 73,04 & 73,91 & 71,30 & 73,04 & 74,78 & 73,91 & 70,43 & 76,52 & 78,26 & 75,65 & 72,17 \\
\hline 19 & IST-0 & & 70 & \begin{tabular}{|l|}
74,78 \\
\end{tabular} & 74,78 & \begin{tabular}{|l|}
72,17 \\
\end{tabular} & 75,65 & 75,65 & 73,91 & 74,78 & 5,65 & 73,91 & 74,78 & 74,78 & 81,74 & 4,78 & 76,52 \\
\hline 20 & IST-00020 & Riska & 70 & 87,33 & 80,67 & 79,33 & 78,67 & 72,00 & 74,67 & 81,33 & 86,00 & 71,33 & 82,67 & 87,33 & 86,67 & 84,67 & 72,00 \\
\hline
\end{tabular}

Tabel 3. Data Hasil Penilaian Kinerja Instruktur berdasarkan Kuesioner

(C16-C29)

\begin{tabular}{|c|c|c|c|c|c|c|c|c|c|c|c|c|c|c|c|c|}
\hline \multirow{2}{*}{ No } & \multirow{2}{*}{$\begin{array}{c}\text { Nomor } \\
\text { Induk } \\
\text { Instruktur }\end{array}$} & \multirow{2}{*}{ Nama Instruktur } & \multicolumn{14}{|c|}{ Hasil Penilaian } \\
\hline & & & C16 & C17 & C18 & C19 & $\mathrm{C2O}$ & C21 & C22 & C23 & $\mathrm{C24}$ & C25 & C26 & C27 & C28 & C29 \\
\hline 1 & IST-00001 & ssyah & 9,09 & 90,91 & 86,36 & 36,36 & 5,45 & 85,45 & 6,36 & 7,27 & 87,27 & 87,27 & 84,55 & 30,00 & 80,00 & 64,00 \\
\hline 2 & IST-00002 & na & 0,00 & 81,54 & 81,54 & 80,00 & 80,77 & 80,77 & 9,23 & 9,23 & 0,00 & 80,77 & 80,77 & 3,85 & 85,71 & 77,50 \\
\hline 3 & IST-00003 & henza Arsyila & 81,67 & 80,00 & 76,67 & 78,33 & 81,67 & 83,33 & 80,00 & 81,67 & 8,33 & 80,00 & 80,00 & 80,00 & 77,27 & 80,00 \\
\hline 4 & IST-00004 & frizl & 0,00 & 75,38 & 75,38 & 75,38 & 76,92 & 78,46 & 78,46 & 78,46 & 6,92 & 76,92 & 78,46 & 78,46 & 88,00 & 87,14 \\
\hline 5 & IST-00005 & & 67 & 00 & 60,00 & 60,00 & 67 & 60,00 & 66,67 & & 52 & 53,33 & 73,33 & 33 & & 77,27 \\
\hline 6 & IST-00006 & & 00 & 86,67 & 90,00 & 90,00 & 3,33 & 86,67 & 86,67 & 67 & 86,67 & 83,33 & 83,33 & 6,67 & 95,71 & 89,60 \\
\hline 7 & IS & & 7,41 & 67,41 & 67,41 & 69,63 & 66,67 & 74,07 & 80,00 & 7,04 & 74,07 & 70,37 & 63,70 & 69,63 & 81,05 & 89,33 \\
\hline 8 & IST-00008 & & 43 & 80,00 & 82,86 & 77,14 & 82,86 & 82,86 & 81,43 & 1,43 & 77,14 & 78,57 & 85,71 & 85,71 & 87,74 & 96,43 \\
\hline 9 & IST-00009 & & 4,55 & 74,55 & 76,36 & 76,36 & 76,36 & 72,73 & 78,18 & 76,36 & 74,55 & 70,91 & 74,55 & 76,36 & 92,31 & 82,11 \\
\hline 10 & IST-00010 & & 0,00 & 80,00 & 80,00 & 80,00 & 80,00 & 70,00 & 80,00 & 80,00 & 80,00 & 80,00 & 80,00 & 80,00 & 70,00 & 87,74 \\
\hline 11 & IST-00011 & Erwin & 0,00 & 90,00 & 90,00 & 90,00 & 90,00 & 90,00 & 87,50 & 87,50 & 5,00 & 90,00 & 90,00 & 90,00 & 81,11 & 93,85 \\
\hline 12 & IST-00012 & Nadya Zahwa & 7,50 & 89,17 & 88,33 & 87,50 & 86,67 & 87,50 & 87,50 & 87,50 & 8,33 & 87,50 & 87,50 & 88,33 & 96,00 & 70,00 \\
\hline 13 & IST-00013 & & & 75,83 & 72,50 & & 00 & 75,83 & & & 83 & 7 & 67 & 7,50 & 00 & 8,89 \\
\hline 14 & 014 & & & 81,11 & & & 81,11 & 82,22 & & & 83,33 & 82,22 & & 82,22 & 1,11 & 85,45 \\
\hline 15 & IST- & & 6,00 & 96,00 & 96,00 & 96,00 & 96,00 & 96,00 & 96,00 & 96,00 & 96,00 & 96,00 & 96,00 & 96,00 & 79,17 & 80,77 \\
\hline 16 & IST & & 5,00 & 75,00 & 75,00 & 70,00 & 70,00 & 70,00 & 75,00 & 75,00 & 75,00 & 75,00 & 75,00 & 75,00 & 67,14 & 83,33 \\
\hline 17 & IST-00017 & Darwin & 67,78 & 63,33 & 62,22 & 64,44 & 61,11 & 56,67 & 60,00 & 64,44 & 58,89 & 66,67 & 68,89 & 70,00 & 45,19 & 78,46 \\
\hline 18 & IST-00018 & Gusdianto & 73,33 & 70,83 & 73,33 & 78,33 & 79,17 & 71,67 & 73,33 & 74,17 & 76,67 & 78,33 & 70,00 & 79,17 & 81,11 & 60,00 \\
\hline 19 & \begin{tabular}{|l|} 
IST-00019 \\
\end{tabular} & hal & 5,71 & 58,57 & 60,00 & 61,43 & 67,14 & 55,71 & 62,86 & 1,43 & 54,29 & 60,00 & 54,29 & 65,71 & 96,00 & 86,67 \\
\hline 20 & IST-00020 & Riska & 62,22 & 47,41 & 49,63 & 47,41 & 45,19 & 45,93 & 45,93 & 51,85 & 46,67 & 53,33 & 71,85 & 70,37 & 75,00 & 74,0 \\
\hline
\end{tabular}

\section{d. Membership Function}

Dari kriteria penilaian kinerja guru tersebut dapat dijadikan sebagai variabel input untuk nilai fuzzy. Dari variabel input yang sudah terbentuk maka dapat ditentukan fungsi keanggotaanya (membership function) yang ditunjukkan pada tabel 4 .

Tabel 4. Variabel Penilaian Kinerja Instruktur

\begin{tabular}{|l|c|c|c|}
\hline Jenis Variabel & $\begin{array}{c}\text { Kode } \\
\text { Variabel }\end{array}$ & $\begin{array}{c}\text { Semesta } \\
\text { Pembicaraan }\end{array}$ & Himpunan Fuzzy \\
\hline Kualifikasi Akademik & {$[\mathrm{C} 1]$} & {$[\mathrm{D} 3, \mathrm{D} 4, \mathrm{~S} 1, \mathrm{~S} 2]$} & Cukup, Baik, Sangat Baik \\
\hline Pedagodik & {$[\mathrm{C} 2, \mathrm{C} 8]$} & {$[0,100]$} & Tidak Baik, Kurang Baik, \\
\hline
\end{tabular}


Jurnal Sains Komputer \& Informatika (J-SAKTI)

Volume 3 Nomor 2 September 2019, pp. 227-242

ISSN:2548-9771/EISSN:2549-7200

http://tunasbangsa.ac.id/ejurnal/index.php/jsakti

\begin{tabular}{|l|c|c|l|}
\hline Jenis Variabel & $\begin{array}{c}\text { Kode } \\
\text { Variabel }\end{array}$ & $\begin{array}{c}\text { Semesta } \\
\text { Pembicaraan }\end{array}$ & Himpunan Fuzzy \\
\hline Profesional & {$[\mathrm{C} 9, \mathrm{C} 13]$} & {$[0,100]$} & $\begin{array}{l}\text { Cukup, Baik, Sangat Baik } \\
\text { Cukup, Baik, Sangat Baik }\end{array}$ \\
\hline Kepribadian & {$[\mathrm{C} 14, \mathrm{C} 18]$} & {$[0,100]$} & $\begin{array}{l}\text { Tidak Baik, Kurang Baik, } \\
\text { Cukup, Baik, Sangat Baik }\end{array}$ \\
\hline Sosial & {$[\mathrm{C} 19, \mathrm{C} 23]$} & {$[0,100]$} & $\begin{array}{l}\text { Tidak Baik, Kurang Baik, } \\
\text { Cukup, Baik, Sangat Baik }\end{array}$ \\
\hline $\begin{array}{l}\text { karya kreatif atau } \\
\text { inovatif }\end{array}$ & {$[\mathrm{C} 24, \mathrm{C} 28]$} & {$[0,100]$} & $\begin{array}{l}\text { Kurang, Cukup, Baik, } \\
\text { Sangat Baik }\end{array}$ \\
\hline $\begin{array}{l}\text { Membimbing Peserta } \\
\text { Didik }\end{array}$ & {$[\mathrm{C} 29]$} & {$[0,100]$} & $\begin{array}{l}\text { Kurang, Cukup, Baik, } \\
\text { Sangat Baik }\end{array}$ \\
\hline
\end{tabular}

Dari jenis variable input yang ada pada tabel 4 maka dapat digambarkan fungsi keanggotaan (membership function) fuzzy berikut ini:

\section{1) Jenis Variabel Kualifikasi Akademik}

Jenis variabel kualifikasi akademik memiliki satu variabel yaitu jenjang pendidikan digambarkan dengan kurva segitiga yang mempunyai 3 himpunan fuzzy yaitu Sangat Baik, Baik, Cukup yang digambarkan pada gambar 2 .

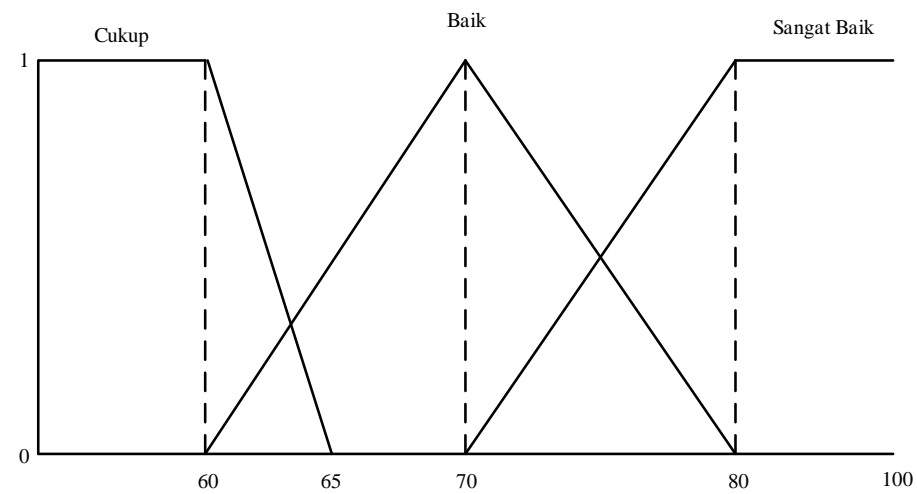

Gambar 2. Fungsi Keanggotaan untuk Jenis Variabel Kualifikasi Akademik

Fungsi keanggotaan untuk masing-masing himpunan adalah:

$\mu$ Cukup $[a]= \begin{cases}1 \frac{65-a}{65-60} & , a \leq 60 \\ 0 & , a>6<6\end{cases}$
$\mu$ Baik $[a]= \begin{cases}0, a-60 & , a<60 \text { atau } a \geq 80 \\ \frac{a-60}{70-6} & , 60 \leq a \leq 70 \\ \frac{80-a}{80-70} & , 70<a<80\end{cases}$

$\mu$ Sangat Baik $[a]= \begin{cases}0 & a-70 \\ \frac{a-70}{80-70} & , 70<a<80 \\ 1 & , a \geq 80\end{cases}$ 


\section{2) Jenis Variabel Pedagodik, Profesional, Kepribadian dan Sosial}

Jenis variabel pedagodik memiliki 7 variabel, professional, kepribadian dan social memiliki 5 variabel, digambarkan dengan kurva segitiga yang mempunyai 3 himpunan fuzzy yaitu Sangat Baik, Baik, Cukup yang digambarkan pada gambar 3 .

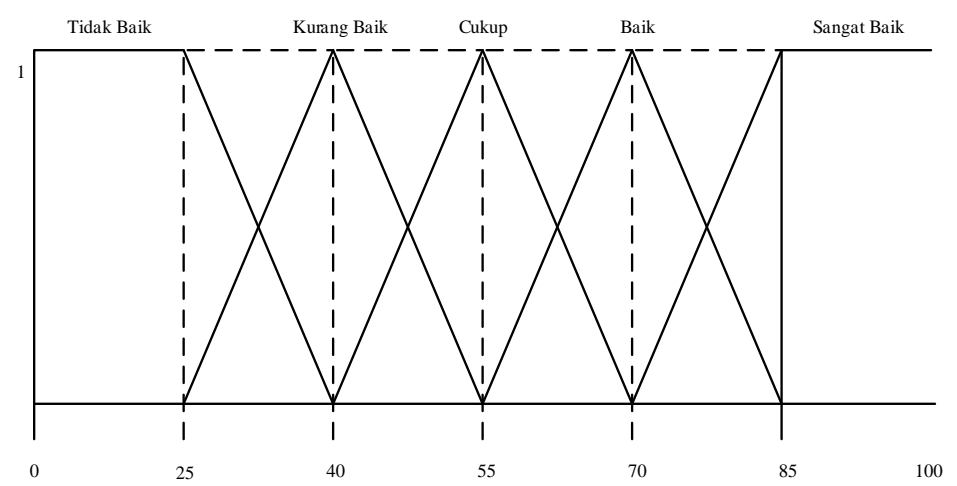

Gambar 3. Fungsi keanggotaan untuk jenis variable pedagodik, professional dan sosial

Fungsi keanggotaan untuk masing-masing himpunan adalah:

$\mu$ Tidak Baik $[x]$

$$
= \begin{cases}1 & 40-x \\ \frac{40-25}{40-25} & , 25 \leq x<40 \\ 0 & , x \geq 40\end{cases}
$$

$\mu$ Kurang Baik $[x]$

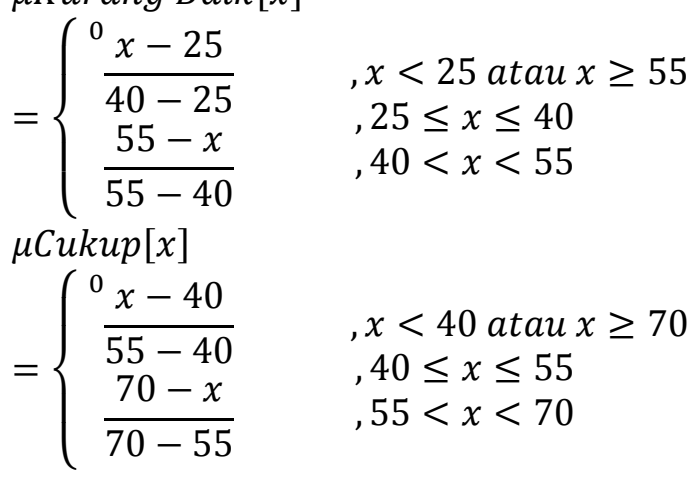

$$
\begin{aligned}
& \mu \text { Baik }[x] \\
& = \begin{cases}0 \frac{x-55}{70-55} & , x<55 \text { atau } x \geq 85 \\
\frac{85-x}{85-70} & , 55 \leq x \leq 70\end{cases}
\end{aligned}
$$$$
\mu \text { Sangat Baik }[x]
$$$$
= \begin{cases}0 x-70 & , x<70 \\ \frac{x-70}{85-70} & , x \geq 85\end{cases}
$$

\section{3) Jenis Variabel Karya Kreatif atau Inovatif dan Membimbing Peserta Didik}

Jenis variabel karya kreatif atau inovatif memiliki 5 variabel, membimbing peserta didik memiliki 1 variabel yang digambarkan dengan kurva segitiga yang mempunyai 4 himpunan fuzzy yaitu Sangat Baik, Baik, Cukup, Kurang Baik yang digambarkan pada gambar 4. 


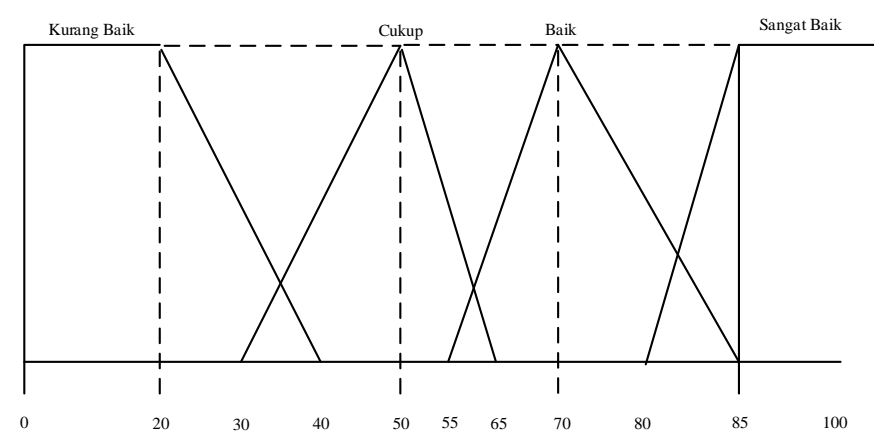

Gambar 4. Fungsi keanggotaan untuk jenis variable karya kreatif atau inovatif

Fungsi keanggotaan untuk masing-masing himpunan adalah: $\mu$ Kurang Baik[x]

$= \begin{cases}1 & 40-x \\ \frac{40-20}{40-20} & , 20 \leq x<40 \\ 0 & , x \geq 40\end{cases}$

$\mu$ Cukup $[\mathrm{x}]$

$=\left\{\begin{array}{cl}\frac{0}{x-30} & , x<50 \text { atau } x \geq 30 \\ 50-30 & , 30 \leq x \leq 50 \\ \frac{65-x}{65-50} & , 50<x<65\end{array}\right.$ $\mu$ Baik $[\mathrm{x}]$

$$
= \begin{cases}\frac{0}{x-55} & , x<55 \text { atau } x \geq 70 \\ \frac{70-55}{85-x} & , 55 \leq x \leq 70 \\ \hline 85-70 & , 70<x<85\end{cases}
$$

$\mu$ Sangat Baik $[\mathrm{x}]$

$$
= \begin{cases}0 & x-80 \\ \frac{85-80}{85} & , x<80 \\ { }_{1} & , x \geq 85<85\end{cases}
$$

\subsection{Hasil Perangkingan}

Hasil Perankingan Selanjutnya, proses perankingan akan dilakukan pada beberapa alternatif yang digunakan sebagai sampel untuk perhitungan manual dengan metode TOPSIS. Di sini data yang digunakan untuk perhitungan manual hanya 5 (lima) buah data saja yang dapat dilihat pada tabel 5 .

\begin{tabular}{|c|c|c|c|c|c|c|c|c|c|c|c|c|c|c|c|c|c|}
\hline \multirow[b]{2}{*}{ No } & \multirow{2}{*}{$\begin{array}{c}\text { Nomor } \\
\text { Induk } \\
\text { Instruktur }\end{array}$} & \multirow[b]{2}{*}{ Nama Instruktur } & \multicolumn{15}{|c|}{ Hasil Penilaian } \\
\hline & & & $\mathrm{Cl}$ & $\mathrm{C} 2$ & $\mathrm{C} 3$ & $\mathrm{C} 4$ & C5 & C6 & C7 & C8 & C9 & $\mathrm{Cl0}$ & Cll & $\mathrm{Cl2}$ & $\mathrm{Cl3}$ & $\mathrm{Cl4}$ & $\mathrm{Cl5}$ \\
\hline 1 & IST-00001 & Budi Hermansyah & 60 & 98,57 & 96,43 & 96,43 & \begin{tabular}{l|l}
95,00 & \\
\end{tabular} & 94,29 & \begin{tabular}{|l|l}
97,14 & 9 \\
\end{tabular} & 96,43 & \begin{tabular}{l|l}
98,57 & 9 \\
\end{tabular} & 96,43 & 95,71 & \begin{tabular}{l|l}
91,43 & $\varsigma$ \\
\end{tabular} & 93,57 & 97,14 & 97,14 \\
\hline 2 & IST-00002 & Andi Pratama & 65 & 81,25 & 77,50 & 80,00 & 80,00 & 78,75 & \begin{tabular}{l|l}
78,75 & 8 \\
\end{tabular} & 80,00 & \begin{tabular}{l|l}
78,75 & 7 \\
\end{tabular} & 78,75 & 81,25 & 81,257 & 78,75 & 80,00 & 80,00 \\
\hline 3 & IST-00003 & Khenza Arsyila Putri & 70 & 78,46 & 80,00 & 80,00 & \begin{tabular}{l|l}
80,00 & 8
\end{tabular} & 80,00 & \begin{tabular}{l|l}
81,54 & 7 \\
\end{tabular} & 78,46 & \begin{tabular}{l|l}
83,08 & 8 \\
\end{tabular} & 80,00 & 80,00 & \begin{tabular}{l|l}
81,54 & 8 \\
\end{tabular} & 80,00 & 80,00 & 80,00 \\
\hline 4 & IST-00004 & Syafrizal & 80 & 73,33 & 70,00 & 70,00 & \begin{tabular}{l|l}
73,33 & 8 \\
7
\end{tabular} & 83,33 & \begin{tabular}{l|l}
56,67 & 8 \\
\end{tabular} & 80,00 & \begin{tabular}{l|l}
73,33 & 7 \\
\end{tabular} & 73,33 & 73,33 & \begin{tabular}{l|l}
66,67 & 7
\end{tabular} & 76,67 & 83,33 & 76,67 \\
\hline 5 & IST-00005 & & 80 & 64,00 & 63,88 & 60,60 & \begin{tabular}{l|l}
61,80 & \\
\end{tabular} & 64,00 & \begin{tabular}{|l|l}
65,65 & 6 \\
\end{tabular} & 64,00 & \begin{tabular}{l|l}
67,67 & 6 \\
\end{tabular} & 64,00 & 60,00 & \begin{tabular}{l|l}
66,50 & 6 \\
\end{tabular} & 64,00 & 64,00 & 68,80 \\
\hline \multirow[b]{2}{*}{ No } & Nomor & \multirow[b]{2}{*}{ Nama Instruktur } & \multicolumn{15}{|c|}{ Hasil Penilaian } \\
\hline & $\begin{array}{c}\text { Induk } \\
\text { Instruktur }\end{array}$ & & $\mathrm{Cl} 16$ & $\mathrm{Cl} 7$ & C18 & $\mathrm{Cl} 9$ & $\mathrm{C20}$ & $\mathrm{C} 21$ & $\mathrm{C} 22$ & $\mathrm{C} 23$ & $\mathrm{C} 24$ & $\mathrm{C} 25$ & $\mathrm{C} 26$ & $\mathrm{C} 27$ & $\mathrm{C} 28$ & & $\mathrm{C} 29$ \\
\hline 1 & IST-00001 & Budi Hermansyah & 89,09 & \begin{tabular}{|l|l|}
9 & 90,91 \\
\end{tabular} & \begin{tabular}{|l|l|}
1 & 86,36 \\
\end{tabular} & \begin{tabular}{|l|l|}
6 & 86,3 \\
\end{tabular} & \begin{tabular}{l|l|}
6 & 85,45 \\
\end{tabular} & \begin{tabular}{l|l}
5 & 85,45 \\
\end{tabular} & \begin{tabular}{|l|l}
5 & 86,36 \\
\end{tabular} & \begin{tabular}{l|l}
6 & 87,27 \\
\end{tabular} & \begin{tabular}{l|l|}
7 & 87,27 \\
\end{tabular} & \begin{tabular}{l|l}
7 & 87,27 \\
\end{tabular} & \begin{tabular}{l|l}
7 & 84,55 \\
\end{tabular} & $5,80,00$ & \begin{tabular}{l|l}
0 & 80,00 \\
\end{tabular} & & 64,00 \\
\hline 2 & IST-00002 & Andi Pratama & 80,00 & \begin{tabular}{l|l}
0 & 81,54 \\
\end{tabular} & \begin{tabular}{|l|l|}
4 & 81,54 \\
\end{tabular} & \begin{tabular}{|l|l|}
4 & 80,0 \\
\end{tabular} & \begin{tabular}{l|l|}
0 & 80,77 \\
\end{tabular} & \begin{tabular}{l|l}
7 & 80,77 \\
\end{tabular} & \begin{tabular}{l|l}
7 & 79,23 \\
\end{tabular} & \begin{tabular}{|l|l|}
3 & 79,23 \\
\end{tabular} & \begin{tabular}{|l|l|}
3 & 80,00 \\
\end{tabular} & 80,77 & \begin{tabular}{l|l}
7 & 80,77 \\
\end{tabular} & \begin{tabular}{l|l}
7 & 83,85 \\
\end{tabular} & \begin{tabular}{l|l}
5 & 85,71 \\
\end{tabular} & & 77,50 \\
\hline 3 & IST-00003 & Khenza Arsyila Putri & 81,67 & \begin{tabular}{l|l}
7 & 80,00 \\
\end{tabular} & \begin{tabular}{l|l}
0 & 76,67 \\
\end{tabular} & \begin{tabular}{|l|l}
7 & 78,3 \\
\end{tabular} & \begin{tabular}{|l|l|}
3 & 81,67 \\
\end{tabular} & \begin{tabular}{|l|l|}
7 & 83,33 \\
\end{tabular} & \begin{tabular}{|l|l}
3 & 80,00 \\
\end{tabular} & \begin{tabular}{l|l}
0 & 81,67 \\
\end{tabular} & $\begin{array}{ll}7 & 78,33 \\
\end{array}$ & 80,00 & \begin{tabular}{l|l}
0 & 80,00 \\
\end{tabular} & $\begin{array}{ll}0 & 80,00 \\
\end{array}$ & \begin{tabular}{l|l}
0 & 77,27 \\
\end{tabular} & & 80,00 \\
\hline 4 & IST-00004 & Syafrizal & 80,00 & \begin{tabular}{l|l}
0 & 75,38 \\
\end{tabular} & \begin{tabular}{|l|l|}
8 & 75,38 \\
\end{tabular} & \begin{tabular}{|l|l|}
8 & 75,3 \\
\end{tabular} & \begin{tabular}{|l|l|}
8 & 76,92 \\
\end{tabular} & \begin{tabular}{|l|l|}
2 & 78,46 \\
\end{tabular} & \begin{tabular}{l|l}
6 & 78,46 \\
\end{tabular} & \begin{tabular}{l|l}
6 & 78,46 \\
\end{tabular} & \begin{tabular}{l|l|}
6 & 76,92 \\
\end{tabular} & \begin{tabular}{|l|l|}
2 & 76,92 \\
\end{tabular} & \begin{tabular}{|l|l|}
2 & 78,46 \\
\end{tabular} & \begin{tabular}{l|l}
6 & 78,46 \\
\end{tabular} & \begin{tabular}{|l|l|}
6 & 88,00 \\
\end{tabular} & & 87,14 \\
\hline 5 & IST-00005 & Lulu Tantika & 66,67 & \begin{tabular}{l|l}
7 & 60,00 \\
\end{tabular} & $\begin{array}{ll}0 & 60,00 \\
\end{array}$ & $\begin{array}{ll}0 & 60,0 \\
\end{array}$ & $\begin{array}{ll}0 & 66,67 \\
\end{array}$ & \begin{tabular}{l|l}
7 & 60,00 \\
\end{tabular} & \begin{tabular}{|l|l}
0 & 66,67 \\
\end{tabular} & \begin{tabular}{l|l}
7 & 66,67 \\
\end{tabular} & \begin{tabular}{l|l}
7 & 64,52 \\
\end{tabular} & \begin{tabular}{|l|l}
2 & 53,33 \\
\end{tabular} & \begin{tabular}{l|l}
3 & 73,33 \\
\end{tabular} & \begin{tabular}{|l|l|}
3 & 73,33 \\
\end{tabular} & \begin{tabular}{|l|l|}
3 & 87,33 \\
\end{tabular} & & 77,27 \\
\hline
\end{tabular}

Tabel 5. Data Hasil Penilaian Kinerja Instruktur

Berdasarkan data pada tabel 5, dapat dibentuk matriks keputusan D yang telah dikonversikan dengan bilangan oleh proses fuzzifikasi sebelumnya, dari sampel yang di ambil adalah hasil Keputusan dengan operator OR pada tabel 6. 
Tabel 6. Rating kecocokan dari setiap alternatif pada setiap kriteria

\begin{tabular}{|c|c|c|c|c|c|c|c|c|c|c|c|c|c|c|c|}
\hline Alternatif & C1 & $\mathrm{C} 2$ & C3 & C4 & C5 & C6 & C7 & C8 & C9 & C10 & C11 & C12 & C13 & C14 & C15 \\
\hline Budi Hermansyah & 0,00 & 0,00 & 0,00 & 0,00 & 0,00 & 0,00 & 0,00 & 0,00 & 0,00 & 0,00 & 0,00 & 0,00 & 0,00 & 0,00 & 0,00 \\
\hline \begin{tabular}{|l} 
Andi Pratama \\
\end{tabular} & 0,50 & 0,25 & 0,50 & 0,33 & 0,33 & 0,42 & 0,42 & 0,33 & 0,42 & 0,42 & 0,25 & 0,25 & 0,42 & 0,33 & 0,33 \\
\hline Khenza Arsyila Putri & 1,00 & 0,44 & 0,33 & 0,33 & 0,33 & 0,33 & 0,23 & 0,44 & 0,13 & 0,33 & 0,33 & 0,23 & 0,33 & 0,33 & 0,33 \\
\hline \begin{tabular}{|l} 
Syafrizal \\
\end{tabular} & 1,00 & 0,78 & 1,00 & 1,00 & 0,78 & 0,11 & 0,89 & 0,33 & 0,78 & 0,78 & 0,78 & 0,22 & 0,56 & 0,11 & 0,56 \\
\hline Lulu Tantika & 1,00 & 0,40 & 0,41 & 0,63 & 0,55 & 0,40 & 0,29 & 0,40 & 0,16 & 0,40 & 0,67 & 0,23 & 0,40 & 0,40 & 0,08 \\
\hline Alternatif & C16 & C17 & C18 & C19 & $\mathrm{C20}$ & C21 & C22 & C23 & C24 & C25 & C26 & C27 & C28 & C29 & \\
\hline Budi Hermansyah & 0,00 & 0,00 & 0,00 & 0,00 & 0,00 & 0,00 & 0,00 & 0,00 & 1,00 & 0,00 & 0,03 & 0,33 & 0,33 & 0,00 & \\
\hline Andi Pratama & 0,33 & 0,23 & 0,23 & 0,33 & 0,28 & 0,28 & 0,38 & 0,38 & 0,33 & 0,28 & 0,28 & 0,08 & 1,00 & 0,50 & \\
\hline Khenza Arsyila Putri & 0,22 & 0,33 & 0,56 & 0,44 & 0,22 & 0,11 & 0,33 & 0,22 & 0,44 & 0,33 & 0,33 & 0,33 & 0,52 & 0,33 & \\
\hline Syafrizal & 0,33 & 0,64 & 0,64 & 0,64 & 0,54 & 0,44 & 0,44 & 0,44 & 0,54 & 0,54 & 0,44 & 0,44 & 1,00 & 1,00 & \\
\hline Lulu Tantika & 0,22 & 0,67 & 0,67 & 0,67 & 0,22 & 0,67 & 0,22 & 0,22 & 0,63 & 0,00 & 0,78 & 0,78 & 1,00 & 0,52 & \\
\hline
\end{tabular}

Langkah 1 adalah normalisasi matriks keputusan

langkah selanjutnya yaitu melakukan normalisasi matrik keputusan (D) dari tabel 6 sampel data nilai siswa penerbangan dengan menggunakan rumus persamaan (1).

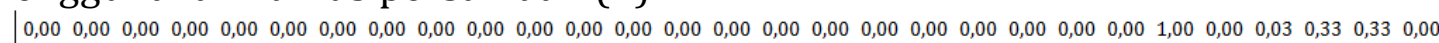
$\begin{array}{llllllllllllllllllllllllllllllll}0,50 & 0,25 & 0,50 & 0,33 & 0,33 & 0,42 & 0,42 & 0,33 & 0,42 & 0,42 & 0,25 & 0,25 & 0,42 & 0,33 & 0,33 & 0,33 & 0,23 & 0,23 & 0,33 & 0,28 & 0,28 & 0,38 & 0,38 & 0,33 & 0,28 & 0,28 & 0,08 & 1,00 & 0,50\end{array}$

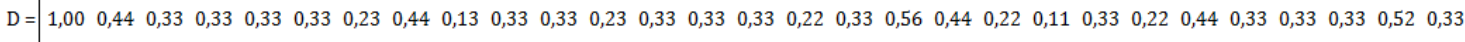
$\begin{array}{llllllllllllllllllllllllllllllllll}1,00 & 0,78 & 1,00 & 1,00 & 0,78 & 0,11 & 0,89 & 0,33 & 0,78 & 0,78 & 0,78 & 0,22 & 0,56 & 0,11 & 0,56 & 0,33 & 0,64 & 0,64 & 0,64 & 0,54 & 0,44 & 0,44 & 0,44 & 0,54 & 0,54 & 0,44 & 0,44 & 1,00 & 1,00\end{array}$

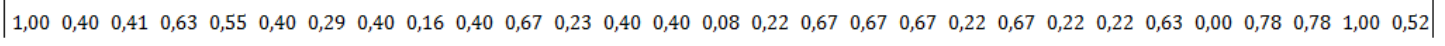

Langkah 2 adalah menghitung Normalisasi

Setelah melakukan normalisasi matrik keputusan (D) pada langkah 1 maka proses selanjutnya adalah menghitung nilai $|\mathrm{Xi}|$ dengan persamaan (3), contoh menghitung nilai |Xi|

$|\mathrm{Xi}|=\sqrt{0.00^{2}+0,50^{2}+1.00^{2}+1,00^{2}+1,00^{2}}=1,8028$

Hasil menghitung nilai $|\mathrm{Xi}|$ dapat dilihat pada tabel 7 .

Tabel 7. Hasil Nilai $|\mathrm{Xi}|$

\begin{tabular}{|c|c|c|c|c|c|c|c|c|c|c|c|c|c|c|c|}
\hline Krit & C1 & $\mathrm{C} 2$ & C3 & C4 & C5 & C6 & C7 & C8 & C9 & C10 & C11 & C12 & C13 & C14 & C15 \\
\hline$|\mathbf{X i}|$ & 1,80 & 1,01 & 1,24 & 1,27 & 1,06 & 68 & 05 & 76 & 0,91 & 1,02 & 1,11 & 47 & 87 & 0,63 & 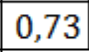 \\
\hline Krit & C16 & C17 & C18 & C19 & $\mathrm{C} 20$ & C21 & C22 & C23 & C24 & C25 & C26 & C27 & C28 & C29 & \\
\hline$|\mathbf{X i}|$ & 0,57 & 1,01 & 1,10 & 1,08 & 0,68 & 0,85 & 0,71 & 0,66 & 1,41 & 0,69 & 0,99 & 1,01 & 1,84 & 1,28 & \\
\hline
\end{tabular}

Menghitung normalisasi $\left({ }^{R_{i j}}\right)$ dengan persamaan (4) dari matrik keputusan (D) dibagi dengan nilai |Xi| dari table 7, sampel mencari nilai normalisasi.

$R_{11}=\frac{0,00}{1.80}=0.00 \quad R_{21}=\frac{0,50}{1.80}=0.28 \quad R_{31}=\frac{1,00}{1.80}=0.55$

Hasil menghitung normalisasi $\left({ }^{R_{i j}}\right)$ dapat dilihat pada tabel 8 . 
Tabel 8. Hasil Nilai Normalisasi

\begin{tabular}{|r|l|c|c|c|c|c|}
\hline \multirow{2}{*}{ No } & \multirow{2}{*}{ Kriteria } & \multicolumn{5}{|c|}{ Instruktur } \\
\cline { 3 - 7 } & & $\mathbf{1}$ & $\mathbf{2}$ & $\mathbf{3}$ & $\mathbf{4}$ & $\mathbf{5}$ \\
\hline 1 & C1 & 0,00 & 0,28 & 0,55 & 0,55 & 0,55 \\
\hline 2 & C2 & 0,00 & 0,14 & 0,24 & 0,43 & 0,22 \\
\hline 3 & C3 & 0,00 & 0,28 & 0,18 & 0,55 & 0,23 \\
\hline 4 & C4 & 0,00 & 0,18 & 0,18 & 0,55 & 0,35 \\
\hline 5 & C5 & 0,00 & 0,18 & 0,18 & 0,43 & 0,30 \\
\hline 6 & C6 & 0,00 & 0,23 & 0,18 & 0,06 & 0,22 \\
\hline 7 & C7 & 0,00 & 0,23 & 0,13 & 0,49 & 0,16 \\
\hline 8 & C8 & 0,00 & 0,18 & 0,24 & 0,18 & 0,22 \\
\hline 9 & C9 & 0,00 & 0,23 & 0,07 & 0,43 & 0,09 \\
\hline 10 & C10 & 0,00 & 0,23 & 0,18 & 0,43 & 0,22 \\
\hline 11 & C11 & 0,00 & 0,14 & 0,18 & 0,43 & 0,37 \\
\hline 12 & C12 & 0,00 & 0,14 & 0,13 & 0,12 & 0,13 \\
\hline 13 & C13 & 0,00 & 0,23 & 0,18 & 0,31 & 0,22 \\
\hline 14 & C14 & 0,00 & 0,18 & 0,18 & 0,06 & 0,22 \\
\hline 15 & C15 & 0,00 & 0,18 & 0,18 & 0,31 & 0,04 \\
\hline
\end{tabular}

\begin{tabular}{|c|l|c|c|c|c|c|}
\hline \multirow{2}{*}{ No } & \multirow{2}{*}{ Kriteria } & \multicolumn{5}{|c|}{ Instruktur } \\
\cline { 2 - 7 } & & $\mathbf{1}$ & $\mathbf{2}$ & $\mathbf{3}$ & $\mathbf{4}$ & $\mathbf{5}$ \\
\hline 17 & C17 & 0,00 & 0,13 & 0,18 & 0,36 & 0,37 \\
\hline 18 & C18 & 0,00 & 0,13 & 0,31 & 0,36 & 0,37 \\
\hline 19 & C19 & 0,00 & 0,18 & 0,25 & 0,36 & 0,37 \\
\hline 20 & C20 & 0,00 & 0,16 & 0,12 & 0,30 & 0,12 \\
\hline 21 & C21 & 0,00 & 0,16 & 0,06 & 0,24 & 0,37 \\
\hline 22 & C22 & 0,00 & 0,21 & 0,18 & 0,24 & 0,12 \\
\hline 23 & C23 & 0,00 & 0,21 & 0,12 & 0,24 & 0,12 \\
\hline 24 & C24 & 0,55 & 0,18 & 0,25 & 0,30 & 0,35 \\
\hline 25 & C25 & 0,00 & 0,16 & 0,18 & 0,30 & 0,00 \\
\hline 26 & C26 & 0,02 & 0,16 & 0,18 & 0,24 & 0,43 \\
\hline 27 & C27 & 0,18 & 0,04 & 0,18 & 0,24 & 0,43 \\
\hline 28 & C28 & 0,18 & 0,55 & 0,29 & 0,55 & 0,55 \\
\hline 29 & C29 & 0,00 & 0,28 & 0,18 & 0,55 & 0,29 \\
\hline
\end{tabular}

Langkah 3 adalah menghitung nilai normalisasi terbobot

Untuk menghitung normalisasi terbobot $\left(Y_{i j}\right)$ dengan menggunakan persamaan (5). Dimana nilai bobot masing criteria $\left(\mathrm{W}_{\mathrm{i}}\right)\left[\begin{array}{l}6 \\ 6\end{array} 6665785\right.$ 855748 8] untuk nilai bobot masing-masing jurusan dikali dengan nilai normalisasi $\left(\mathrm{R}_{\mathrm{ij}}\right)$ pada table 6 . Berikut adalah contoh untuk menghitung nilai normalisasi terbobot.

$$
\mathrm{Y}_{11}=(8)(0)=0 \quad \mathrm{Y}_{12}=(8)(0)=0
$$

Hasil nilai normalisasi terbobot $\left(Y_{i j}\right)$ dengan menggunakan persamaan (5) dapat dilihat pada table 9.

Tabel 9. Hasil Nilai Normalisasi Terbobot

\begin{tabular}{|r|c|c|c|c|c|c|}
\hline \multirow{2}{*}{ No } & \multirow{2}{*}{ Kriteria } & \multicolumn{5}{|c|}{ Instruktur } \\
\cline { 3 - 7 } & & $\mathbf{1}$ & $\mathbf{2}$ & $\mathbf{3}$ & $\mathbf{4}$ & $\mathbf{5}$ \\
\hline 1 & C1 & 0,00 & 2,22 & 4,44 & 4,44 & 4,44 \\
\hline 2 & C2 & 0,00 & 0,97 & 1,69 & 3,02 & 1,55 \\
\hline 3 & C3 & 0,00 & 1,94 & 1,29 & 3,88 & 1,58 \\
\hline 4 & C4 & 0,00 & 1,29 & 1,29 & 3,88 & 2,43 \\
\hline 5 & C5 & 0,00 & 1,29 & 1,29 & 3,02 & 2,12 \\
\hline 6 & C6 & 0,00 & 1,62 & 1,29 & 0,43 & 1,55 \\
\hline 7 & C7 & 0,00 & 1,62 & 0,90 & 3,45 & 1,13 \\
\hline 8 & C8 & 0,00 & 1,29 & 1,69 & 1,29 & 1,55 \\
\hline 9 & C9 & 0,00 & 1,39 & 0,43 & 2,59 & 0,52 \\
\hline 10 & C10 & 0,00 & 1,39 & 1,11 & 2,59 & 1,33 \\
\hline 11 & C11 & 0,00 & 0,83 & 1,11 & 2,59 & 2,22 \\
\hline 12 & C12 & 0,00 & 0,83 & 0,77 & 0,74 & 0,78 \\
\hline 13 & C13 & 0,00 & 1,39 & 1,11 & 1,85 & 1,33 \\
\hline 14 & C14 & 0,00 & 0,92 & 0,92 & 0,31 & 1,11 \\
\hline 15 & C15 & 0,00 & 0,92 & 0,92 & 1,54 & 0,22 \\
\hline
\end{tabular}

\begin{tabular}{|c|c|c|c|c|c|c|}
\hline \multirow{2}{*}{ No } & \multirow{2}{*}{ Kriteria } & \multicolumn{5}{|c|}{ Instruktur } \\
\cline { 3 - 7 } & & $\mathbf{1}$ & $\mathbf{2}$ & $\mathbf{3}$ & $\mathbf{4}$ & $\mathbf{5}$ \\
\hline 16 & C16 & 0,00 & 2,94 & 1,96 & 2,94 & 1,96 \\
\hline 17 & C17 & 0,00 & 0,64 & 0,92 & 1,78 & 1,85 \\
\hline 18 & C18 & 0,00 & 0,64 & 1,54 & 1,78 & 1,85 \\
\hline 19 & C19 & 0,00 & 0,74 & 0,99 & 1,42 & 1,48 \\
\hline 20 & C20 & 0,00 & 0,63 & 0,49 & 1,20 & 0,49 \\
\hline 21 & C21 & 0,00 & 0,63 & 0,25 & 0,97 & 1,48 \\
\hline 22 & C22 & 0,00 & 0,85 & 0,74 & 0,97 & 0,49 \\
\hline 23 & C23 & 0,00 & 0,85 & 0,49 & 0,97 & 0,49 \\
\hline 24 & C24 & 1,66 & 0,55 & 0,74 & 0,90 & 1,06 \\
\hline 25 & C25 & 0,00 & 0,47 & 0,55 & 0,90 & 0,00 \\
\hline 26 & C26 & 0,05 & 0,47 & 0,55 & 0,73 & 1,29 \\
\hline 27 & C27 & 0,55 & 0,13 & 0,55 & 0,73 & 1,30 \\
\hline 28 & C28 & 0,55 & 1,66 & 0,87 & 1,66 & 1,66 \\
\hline 29 & C29 & 0,00 & 2,22 & 1,46 & 4,44 & 2,31 \\
\hline
\end{tabular}


Langkah 4 mengidentifikasi solusi ideal positif dan solusi ideal negative.

Solusi ideal positif $(\mathrm{A}+)$ diperoleh dengan mencari nilai maksimal dari nilai normalisasi terbobot (yij) untuk masing-masing siswa dari tabel 9 dengan menggunakan persamaan (6) dan solusi ideal negatif (A-) diperoleh dengan mencari nilai minimal dari nilai normalisasi terbobot (yij) untuk masing-masing siswa dari tabel 9 dengan menggunakan persamaan (7).

$\mathrm{A}+=(4,44 ; 3,02 ; 3,88 ; 3,88 ; 3,02 ; 1,62 ; 3,45 ; 1,69 ; 2,59 ; 2,59 ; 2,59 ; 0,83$;

1,$85 ; 1,11 ; 1,54 ; 2,94 ; 1,85 ; 1,85 ; 1,48 ; 1,2 ; 1,48 ; 0,97 ; 0,97 ; 1,66$;

$0,90 ; 1,29 ; 1,30 ; 1,66 ; 4,44)$

A-

$(0 ; 0 ; 0 ; 0 ; 0 ; 0 ; 0 ; 0 ; 0 ; 0 ; 0 ; 0 ; 0 ; 0 ; 0 ; 0 ; 0 ; 0 ; 0 ; 0 ; 0 ; 0 ; 0 ; 0,55 ; 0 ; 0,05 ; 0,13 ; 0,55$;

$0)$

Langkah 5 menghitung jarak antara setiap alternatif dengan solusi ideal positif dan solusi ideal negatif

Jarak antara alternatif Ai dengan solusi ideal positif (yj+) yang dinyatakan dengan simbol $\mathrm{Di}+$ diperoleh dari nilai akar dari jumlah nilai tiap alternatif yang diperoleh dengan nilai normalisasi terbobot untuk setiap jurusan (yij) pada tabel 9 di kurangi solusi ideal positif (yi+) masing-masing siswa kemudian di pangkat dua dengan menggunakan persamaan (8).

Hasil nilai Jarak $\left(\mathrm{Di}^{+}\right)$antara alternatif Ai dengan solusi ideal positif (yj+) dapat dilihat pada tabel 10 .

Tabel 10. Hasil Nilai Jarak

\begin{tabular}{|l|c|c|c|c|c|}
\hline Instruktur & $\mathbf{1}$ & $\mathbf{2}$ & $\mathbf{3}$ & $\mathbf{4}$ & $\mathbf{5}$ \\
\hline $\mathrm{Di}+$ & 12,66 & 6,75 & 7,13 & 14,83 & 5,61 \\
\hline
\end{tabular}

Jarak antara alternatif $A_{i}$ dengan solusi ideal negatif (yj-) yang dinyatakan dengan simbol Di- diperoleh dari nilai akar dari jumlah nilai tiap alternatif yang diperoleh dengan nilai ternormalisasi terbobot untuk setiap jurusan $\left(\mathrm{y}_{\mathrm{ij}}\right)$ di kurangi solusi ideal negatif dari masing-masing siswa (yj-) kemudian di pangkat dua dengan menggunakan persamaan (9). Hasil nilai jarak (Di-) antara alternatif Ai dengan solusi ideal negatif (yj-) dapat dilihat pada tabel 11.

Tabel 11. Hasil Nilai Jarak (Di-)

\begin{tabular}{|l|c|c|c|c|c|}
\hline Instruktur & $\mathbf{1}$ & $\mathbf{2}$ & $\mathbf{3}$ & $\mathbf{4}$ & $\mathbf{5}$ \\
\hline $\mathrm{Di}^{-}$ & 1,18 & 6,90 & 7,16 & 12,34 & 8,79 \\
\hline
\end{tabular}

Langkah 6 menentukan nilai kedekatan setiap alternatif terhadap solusi ideal Nilai $V_{i}$ (nilai preferensi untuk setiap alternatif) dimana nilai $\mathrm{Di}^{-}$ dibagi dengan jumlah nilai $\mathrm{Di}^{-}$ditambah jumlah nilai $\mathrm{Di}^{+}$dengan 
menggunakan persamaan (10). Contoh berikut adalah untuk menghitung nilai preferensi.

$$
\mathrm{V}_{1}=\frac{1,88}{1,88+12.66}=0,09
$$

Berdasarkan perhitungan nilai $V_{\text {i }}$ (nilai preferensi untuk setiap alternatif) maka diperoleh hasil akhir dari setiap alternatif pada tabel 12 .

Tabel 12. Hasil Penilaian Pemilihan Jurusan

\begin{tabular}{|l|c|c|c|c|c|}
\hline Instruktur & $\mathbf{1}$ & $\mathbf{2}$ & $\mathbf{3}$ & $\mathbf{4}$ & $\mathbf{5}$ \\
\hline $\mathrm{V}_{\mathrm{i}}$ & 0,09 & 0,51 & 0,50 & 0,45 & 0,61 \\
\hline
\end{tabular}

\subsection{Uji Validasi}

Berdasarkan hasil penilaian kinerja instruktur penerbangan yang tertuang pada table 12, maka urutan rangking pertama pada instruktur 5 dengan nilai 0,61 , rangking kedua pada instruktur 2 dengan nilai 0,51 , rangking ketiga pada instruktur 3 dengan nilai 0,50, rangking keempat pada instruktur 4 dengan nilai 0,45 dan urutan rangking terakhir pada instruktur 1 dengan nilai 0,09. Untuk rekomendasi kepada pihak manajemen LPP untuk kualitas kinerja instruktur yang paling baik adalah Lulu Tantika (Instruktur 5) dengan nilai 0,61. Hasil penilaian kinerja instruktur penerbangan dengan kombinasi metode Fuzzy Tahani dan TOPSIS, berdasarkan pada 250 data yang diuji sampel, oleh karena itu, nilai akurasi adalah sebanyak $93 \%$.

\section{SIMPULAN}

Analisa pengujian akurasi sistem dapat menunjukkan bahwa pemodelan sistem pendukung keputusan dengan kombinasi dua metode yaitu metode Fuzzy Tahani dan TOPSIS sangat tepat digunakan untuk mengatasi masalah terhadap manipulasi data-data keberhasilan Instruktur mengajar yang bersifat ambigu, dimana model ini dapat melakukan pencarian data yang tepat dan akurat berdasarkan kriteria yang dipakai dalam proses penilaian kinerja instruktur LPP Penerbangan dengan menggunakan Fuzzy-Tahani untuk mendapatkan perioritas kriteria dalam bentuk rule, kemudian akan dilakukan perangkingan dengan menggunakan TOPSIS dalam mendapatkan kualitas pengajaran yang dilakukan oleh Instruktur LPP Penerbangan sebagai pemilihan intruktur terbaik.

\section{UCAPAN TERIMA KASIH}

Penulis mengucapkan terima kasih kepada Kementerian Riset, Teknologi dan Pendidikan Tinggi Republik Indonesia (Ristekdikti) yang telah membantu penulis dalam penelitian ini . 


\section{DAFTAR PUSTAKA}

[1] Saaty, T. L., Peniwati, K., 2008, Group Decision Making: Drawing Out and Reconcilling Differences, RWS Publications, Pittsburgh.

[2] Lestari, W.O., 2009. Sistem Pendukung Keputusan Pemilihan Karyawan Terbaik Berdasarkan Penilaian Kinerja Menggunakan Metode Topsis.

[3] Husein, M., 2016. Analisa Sistem Pendukung Keputusan Penilaian Kinerja Kepala Sekolah Tingkat Smp Kabupaten X. CogITo Smart Journal, 2(2), pp.147156.

[4] Juliyanti, M.I.I. and Mukhlash, I., 2011. Pemilihan Guru Berprestasi Menggunakan Metode AHP dan TOPSIS. In Prosiding Seminar Nasional Penelitian, Pendidikan dan Penerapan MIPA, Fakultas MIPA, Universitas Negeri Yogyakarta (Vol. 14).

[5] Safrizal, S., 2014. Rekam Jejak Dosen Sebagai Model Pengambilan Keputusan Dalam Pemilihan Dosen Berprestasi. Creative Information Technology Journal, 2(1), pp.65-76.

[6] Tanti, L., 2016. Multi-Criteria Decision Making Dalam Penentuan Jurusan Siswa Pada Lembaga Pendidikan dan Pelatihan (LPP) Penerbangan. Journal of Applied Intelligent System, 1(3), pp.154-166.

[7] Safrizal, S., 2016. EVALUASI KINERJA INSTRUKTUR UNTUK MENINGKATKAN PROFESIONALISME PADA LEMBAGA PENDIDIKAN DAN PELATIHAN PENERBANGAN. SEMNASTEKNOMEDIA ONLINE, 4(1), pp.1-3.

[8] Kusumadewi, Sri dan Purnomo, Hari. 2004. Aplikasi Logika Fuzzy untuk Pendukung Keputusan. Yogyakarta:Graha Ilmu.

[9] Turban, E., Aronson, J., E., dan Liang, T., P., 2005. Sistem Pendukung Keputusan dan Sistem Cerdas. Terjemahan Dwi Prabantini. Yogyakarta: ANDI.

[10] Chamid, A.A., 2016. Penerapan Metode Topsis Untuk Menentukan Prioritas Kondisi Rumah. Simetris: Jurnal Teknik Mesin, Elektro dan Ilmu Komputer, 7(2), pp.537-544.

[11] Prasetiyowati, Maria Irmina. 2007. IMPLEMENTASI FUZZY DATABASE UNTUK MEMBERIKAN REKOMENDASI JALUR PEMINATAN MAHASISWA. Surabaya. SNSI07-028.

[12] Saftizal, S., TANTI, Lili, et al. PENENTUKAN JURUSAN SISWA PADA LEMBAGA PENDIDIKAN DAN PELATIHAN (LPP) PENERBANGAN. In: SISITI: Seminar Ilmiah Sistem Informasi dan Teknologi Informasi. 2017

[13] Safrizal, S. (2016). EVALUASI KINERJA INSTRUKTUR UNTUK MENINGKATKAN PROFESIONALISME PADA LEMBAGA PENDIDIKAN DAN PELATIHAN PENERBANGAN. SEMNASTEKNOMEDIA ONLINE, 4(1), 1-3

[14] Safrizal, S., Tanti, L., Rahmad, I. F., \& Thanri, Y. (2018, August). Monitoring and Evaluation of Flight Instructor Performance with PROMETHEE Method. In 2018 6th International Conference on Cyber and IT Service Management (CITSM) (pp. 1-6). IEEE

[15] Sahir, S. H., Rosmawati, R., \& Rahim, R. (2018). Fuzzy model tahani as a decision support system for selection computer tablet. Int. J. Eng. Technol, 7(2.9), 61-65.

[16] Ginting, G., Fadlina, M., Siahaan, A.P.U. and Rahim, R., 2017. Technical Approach of TOPSIS in Decision Making. Int. J. Recent Trends Eng. Res, 3(8), pp.58-64. 
Jurnal Sains Komputer \& Informatika (J-SAKTI)

Volume 3 Nomor 2 September 2019, pp. 227-242

ISSN:2548-9771/EISSN:2549-7200

http://tunasbangsa.ac.id/ejurnal/index.php/jsakti

[17] Şengül, Ü., Eren, M., Shiraz, S.E., Gezder, V. and Şengül, A.B., 2015. Fuzzy TOPSIS method for ranking renewable energy supply systems in Turkey. Renewable Energy, 75, pp.617-625.

[18] Jasri, D.S. and Rahim, R., 2017. Decision Support System Best Employee Assessments with Technique for Order of Preference by Similarity to Ideal Solution. Int. J. Recent TRENDS Eng. Res, 3(3), pp.6-17.

[19] Tanti, L., Puspasari, R., \& Triandi, B. (2018, August). Employee Performance Assessment with Profile Matching Method. In 2018 6th International Conference on Cyber and IT Service Management (CITSM) (pp. 1-6). IEEE. 